\title{
УДК 338.984
}

DOI https://doi.org/10.32782/2224-6282/149-12

Спірідонова К. О., Черкас В. О.

Придніпровська державна академія будівництва та архітектури

Spiridonova K., Cherkas V.

Prydniprovska State Academy of Civil Engineering and Architecture

\section{СКЛАДАННЯ БІЗНЕС-ПЛАНУ В СУЧАСНИХ УМОВАХ ГОСПОДАРЮВАННЯ}

У статті розглянута проблема прогнозування діяльності підприємства через нестабільність факторів зовнішнього середовища. Розроблений бізнес-план допомагає підприємиям прокласти шлях свого бізнесу від ідеї, яка народилась, до повноиінного та конкурентоспроможного бізнесу. Планування своєї діяльності на перед, значно допомагає у складних реаліях сьогодення, адже близько 98\% невдач у бізнесі пояснюються незадовільним менеджментом. Тобто, коли підприємець не знає, щчо йому треба та у якому русі розвиватись і відбувається занепад кожного бізнесу. Українським підприємствам досить важко працювати у таких умовах і тому посилюється роль бізнес-планування як важливого інструменту стратегічного планування, завдяки якому підприємства можуть визначити мету і місію свого функиіонування, розробляти систему заходів щзодо поліпшення результатів діяльності або запобігання погрозам зовнішнього середовища. Проведені дослідження доводять, шео не дивлячись на стрімкий ріст кількості діючих приватних підприємств з 2013 по 2015 роки, у 2016 і 2017 роках відбувається зниження кількості підприємств. Підприємиі занадто довіряють своїи інтуїиії, а не розрахункам, за допомогою яких можна побудувати прибутковий бізнес. Така ситуаиія доводить про необхідність докладної розробки бізнес-плану, як одного з ключових елементів стратегії діяльності підприємства. Розглянутий спосіб створення бізнес-плану, за стандартом UNIDO, є оптимальним та найбільш поширеним. Він в себе включає вісім пунктів та додатки. У «Резюме» викладається стисла інформація про основні деталі проекту. Будь-яка людина після ознайомлення із ним повинна розуміти про що проект, та яку вигоду можна отримати. "Опис підприємства і галузі» полягає у аналізі можливостей підприємства та його успішності в иій галузі. «Опис продукиї̈» безпосередньо описує сам продукт6 його основні характеристики та переваги над конкурентами. «Маркетинговий план» включає в себе: результати маркетингових досліджень, аналіз ринку, иіноутворення та методи просування на ринку. Наступним пунктом $\epsilon$ «Організаційний план», у якому розраховуються постійні та змінні витрати, та виробничі можливості підприємства. "Фінансовий план» складається з калькуляції собівартості, таблиць витрат і доходів, а також руху коштів. «Ризики і гарантї̈» $є$ заключним пунктом, у якому описуються можслиі ризики проекту та гарантії окупності проекту. Викладена в ньому інформація буде зрозуміла банкам, інвесторам та іншим фінансовим установам у яких власник бізнес-плану може захотіти взяти інвестиційний капітал на свою ідею.

Ключові слова: бізнес-план; конкуренція; зовнішнє середовище; інвестиції; структура бізнес-плану.

\section{BUSINESS PLAN IN MODERN BUSINESS CONDITIONS}

The problem of forecasting the activity of an enterprise due to instability of environmental factors has been considered in the article. The developed business plan helps entrepreneurs to lead the way of their business from a born idea to a full-fledged and competitive business. Planning your business ahead helps a lot in the complex realities of today, as about $98 \%$ of business failures are explained by poor management. That is, when the entrepreneur does not know what he needs and in what movement to develop and the decline of each business. It is quite difficult for Ukrainian businesses to work in such conditions, and therefore the role of business planning as an important strategic planning tool is being strengthened, whereby enterprises can define the purpose and mission of their operation, develop a system of measures to improve performance or prevent threats to the environment. Most foreign investors invest in Ukrainian enterprises only through a detailed analysis of their activities, but when an enterprise is trying to attract external financing, a business plan is an ideal indicator of strategic and operational planning. Studies have shown that despite the rapid growth in the number of operating private enterprises from 2013 to 2015, in 2016 and 2017 there is a decrease in the number of enterprises. Entrepreneurs rely too much on their intuition, not the calculations that can help them build a profitable business. This situation proves the need for detailed development of the business plan, as one of the key elements of the strategy of the enterprise. The considered way of creating a business plan, according to the UNIDO standard, is optimal and most common. It includes eight items and appendices. The Resume outlines basic details of the project. Anyone who is familiar with it should understand what the project is and what the benefits can be. "Description of the enterprise and industry" is to analyze the capabilities of the enterprise and its success in this field. Product Description directly describes the product itself6 its main characteristics and advantages over its competitors. The "Marketing Plan" includes: marketing research results, market analysis, pricing and market promotion methods. The next item is the "Organizational Plan", which calculates fixed and variable costs and production capabilities of the enterprise. A "financial plan" consists of costing, cost and income tables, and cash flow. Risks and Guarantees is the final point that describes the potential risks of the project and the payback of the project. The information contained therein will be clear to banks, investors and other financial institutions where the business plan owner may want to take the investment capital on his idea.

Keywords: business plan; competition; environment; development; business plan structure.

JEL Classification: L21, M20

Актуальність. На сьогоднішній день нестабільність факторів зовнішнього середовища вимагає від підприємств детального прогнозування поточної діяльності 3 метою обгрунтування стратегічних напрямків розвитку, врахування загроз і можливостей подальшого функ- ціонування та досягнення поставлених цілей. Сучасні умови вимагають від будь-якої організації вміння своєчасно приймати обгрунтовані управлінські рішення. В зв'язку з цим посилюється роль бізнес-планування як важливого інструменту стратегічного планування, 
завдяки якому підприємства можуть визначити мету і місію свого функціонування, розробляти систему заходів щодо поліпшення результатів діяльності або запобігання погрозам зовнішнього середовища.

Аналіз останніх досліджень і публікацій. Питання складання бізнес-планів з урахуванням поточної економічної ситуації розглянуті у наукових працях відомих вчених: Н. Крилової, В.А. Чичина [1], К. Кіпермана, І.В. Ліпсіса, Алексєєва М.М. [2], Г.Д. Львовського, В.Д. Маркової, Покропивного С.Ф. [3], М. Муллей, О.І. Пальчик, Смаковська Ю. [4], Г. Пітерса, А.Р. Полякова, Х. Роузена, Ю.І. Скирко, В. Хруцького та ін. На сьогодні існує декілька наукових підходів до розробки бізнес-планів на підприємстві, які обгрунтовані зарубіжними економістами і менеджерами: П. Тіффані, Стівеном Д. Пітерсоном, Х. Роузеном, Р. Уотерменом, та іншими.

Багато аспектів складання та реалізації бізнес-планів повинні підлягати ретельній адаптації до українських реалій та стану перехідної економіки.

Метою статті є визначення сутності та місця бізнес-плану в системі управління підприємницькою діяльністю в сучасних умовах господарювання та аналіз основних розділів бізнес-плану.

Виклад основних результатів дослідження. Бізнеспланування - це дієвий інструмент в сучасному бізнессередовищі. Розробка бізнес-планів і здійснення бізнеспланування діяльності підприємств включає постійний моніторинг ринку, стану конкурентної середи, складання планів для впровадження будь-яких змін.

На відміну від західних країн, ділове планування в Україні має ряд особливостей [1].

Українське законодавство не закріплює обов'язковість розробки бізнес-плану. Останній є новим документом для більшості українських підприємств [2]. Незважаючи на прагнення країни приєднатися до європейської спільноти та підвищити стандарти якості продукції, послуг та принципів ведення бізнесу, значно поширена позиція, яка заперечує доцільність розробки розгорнутого бізнес-плану, оскільки бізнес-умови змінюються занадто швидкими темпами, і передбачає, як альтернативу, стисле технікоекономічне обгрунтування.
Аналіз діяльності зарубіжних фірм показав, що причиною більшості банкрутств є прорахунки або відсутність бізнес-плану, а також підприємці вважають, що 98\% невдач у бізнесі пояснюється незадовільним менеджментом, зокрема $45 \%$ - некомпетентністю, $20 \%$ - низьким професіоналізмом, 18\% - нестачею управлінського досвіду, 9\% - відсутністю досвіду роботи на виробництві, 3\% - невиконанням взятих на себе зобов'язань, 2\% - шахрайством, $1 \%$ - стихійним лихом і лише $2 \%$ - причинами, що не залежать від якості управління фірмою [5].

Бізнес-план дає детальні пояснення, як буде відбуватися управління бізнесом для забезпечення його прибутковості, а також окупності інвестицій. Постійні зміни бізнес-середовища, в якому функціонує підприємство, припускають уточнення і перегляд бізнес-плану, що, в свою чергу, вимагає вироблення механізму залучення управлінського персоналу до такої роботи. У загальному випадку бізнес-план складається для зовнішніх і внутрішніх цілей. Як документ, спрямований для зовнішніх користувачів, бізнес-план призначається для виправдання довіри інвесторів і кредиторів, переконання їх у потенційних можливостях компанії, компетентності іiі співробітників, а також необхідності надання стратегічної і фінансової допомоги. Іншими словами, відсутність обгрунтованого бізнес-плану, відкоригованого відповідно до мінливих умов, свідчить про неефективність управління підприємством та, як наслідок, ускладнює можливості залучення фінансових ресурсів і досягнення довгострокової стабільності в конкурентному середовищі.

Таким чином, бізнес-план можна розглядати як основу планової і оперативної діяльності підприємства. Це найбільш важливе джерело акумуляції стратегічної інформації та інструмент безпосереднього управлінського впливу на майбутнє становище підприємства, що описує шляхи досягнення прибутковості. У цілому фінансова, операційна й інвестиційна політика підприємства повинна відповідати напрямам і стратегічним цілям, викладеним у бізнес-плані [6].

У відповідності до наведених даних спостерігається зростання кількості приватних підприємців в період 2013-2015 років. У 2016 і 2017 роках спостерігається поступове скорочення кількості суб'єктів гос-

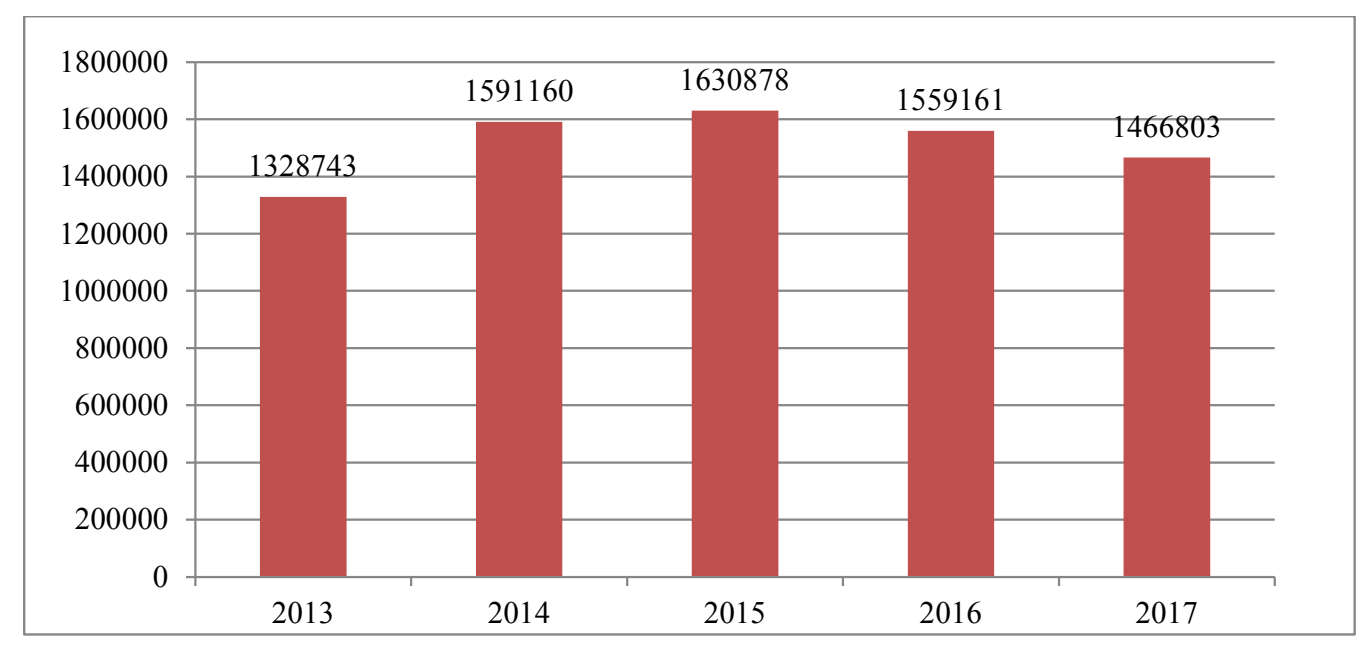

Рис. 1. Кількість діючих приватних підприсмців в Україні за 2013-2017 роки

Дюкерело: розроблено авторами на основі [11] 
подарювання, що свідчить про не підготовленість до реального бізнесу багатьох підприємців. Багато нових гравців на ринку спираються на своє власне відчуття, що дуже часто є не об'єктивним. Адже багато бізнесменів в Україні за 2016 та 2017 припинили свою діяльність, саме через невдалий менеджмент і організацію своєї діяльності, що призвело до втрати конкурентоспроможності. Тому так важливо розробляти бізнес план, аби завжди розуміти всі аспекти своєї діяльності та головну ціль підприємства - отримання прибутку.

В даний час не існують обов'язкові методики підготовки бізнес-плану, проте загальна структура бізнес-плану, відповідно до стандартів 3 інвестицій UNIDO, повинна включати основні складові, представлені у табл. 1 .

Резюме - це самостійний підсумковий документ, тому що в ньому містяться основні положення всього бізнесплану. Це фактично єдина частина, яку читатимуть більшість потенційних інвесторів, тому у резюме міститься інформація, що цікавить інвестора: розмір інвестицій, мета, очікувані терміни погашення, гарантії, інші інвестори, якими активами володіє підприємство [7].

Опис підприємства і галузі. Призначення розділу показати і довести житттєздатність цього бізнесу або ідеї шляхом опису форми практичних дій 3 урахуванням реальної ситуації в обраній сфері бізнесу. У цьому розділі повинні чітко і коротко пояснити два основних моменти:

- що являє собою підприємство як засіб отримання прибутку;

- чим підприємство краще за конкурентів.

У даному розділі повинна міститися інформація наступного характеру:

- чим підприємство займається (буде додатково займатися), опис продукту (послуги), хто є клієнтами;
- опис поточного стану у вибраній сфері бізнесу (як підприємство вписується в обрану сферу бізнесу, стан справ у цій сфері, оцінка перспектив розвитку);

- організаційно-правова форма підприємства, організаційна структура, засновники, персонал і партнери, дата створення;

- фінансово-економічні показники діяльності підприємства;

- місце розташування підприємства (адреса підприємства, характеристика будинку або приміщення, власність або оренда, необхідність реконструкції, тощо);

- специфіка роботи (сезонність, час роботи (години i дні тижня), і інші особливості, пов’язані зі сферою бізнесу або використовуваними ресурсами).

Якщо підприємство тільки створюється, то цей розділ має додатково містити обгрунтування успіху створюваного підприємства і досвід підприємства у даній сфері бізнесу. Зокрема, бажані посилання на договори або попередні домовленості з постачальниками або споживачами. Якщо проект реалізується в рамках індивідуальної підприємницької діяльності, то приводиться опис бізнесу, яким підприємець займаєтеся. Розділ повинен переконати інвестора в надійності і перспективності фірми, що пропонує проект.

Опис продукції (послуг). У цьому розділі слід дати визначення та опис тих видів продукції або послуг, які будуть запропоновані на ринок. Тут слід зазначити деякі аспекти технології, необхідної для виробництва продукції або послуг. Важливо, щоб ця частина була написана зрозумілою, чіткою мовою. Розділ містить опис характеристик продукції, при цьому при цьому необхідно звернути увагу на перевагах, які продукція несе потенційним покупцям.

Структура бізнес- плану (згідно стандарту UNIDO)

Таблиця 1

\begin{tabular}{|c|c|}
\hline \multicolumn{2}{|r|}{ Міжнародний стандарт складання бізнес-плану UNIDO } \\
\hline Розділи & Зміст \\
\hline 1) Резюме & $\begin{array}{l}\text { Розділ повинен містити загальну інформацію про бізнес-план: коротку інформацію щодо сутності } \\
\text { проекту, обсягів інвестицій, власних коштів, термінів реалізації та фінансові показники проекту. }\end{array}$ \\
\hline $\begin{array}{l}\text { 2) Опис } \\
\text { підприємства і галузі }\end{array}$ & $\begin{array}{l}\text { Загальна інформація про компанію, основні показники діяльності, кадровий потенціал, структура } \\
\text { управління, вироблені товари і послуги, партнерські зв'язки, характеристика галузі та ролі компанії } \\
\text { в галузі. }\end{array}$ \\
\hline $\begin{array}{l}\text { 3) Опис продукції } \\
\text { (послуг) }\end{array}$ & $\begin{array}{l}\text { За кожним видом вироблених товарів і послуг повинна бути представлена наступна інформація: } \\
\text { найменування продукції, фотографії, призначення та область застосування, основні характеристики, } \\
\text { конкурентоспроможність, авторські права, наявність або необхідність ліцензування, ступінь } \\
\text { готовності до випуску і реалізації продукції, наявність сертифіката якості, безпека і екологічність, } \\
\text { умови поставки та упаковка, гарантії та сервіс, вимоги до умов експлуатації продукції. }\end{array}$ \\
\hline $\begin{array}{l}\text { 4) Маркетинговий } \\
\text { план }\end{array}$ & $\begin{array}{l}\text { Результати проведення маркетингових досліджень, опис ринку та перспективи його розвитку, опис } \\
\text { конкурентів, принципи формування ціни на вироблену продукцію, система розподілу та просування. }\end{array}$ \\
\hline 5) Виробничий план & $\begin{array}{l}\text { Розрахунок постійних і змінних витрат залежно від обсягів виробництва, розрахунок собівартості } \\
\text { продукції, інформація щодо виробничих можливостей підприємства. }\end{array}$ \\
\hline $\begin{array}{l}\text { 6) Організаційний } \\
\text { план }\end{array}$ & $\begin{array}{l}\text { Опис організаційної структури підприємства та етапів реалізації проекту, менеджменту і складу } \\
\text { технічного персоналу, способів мотивації працівників. }\end{array}$ \\
\hline 7) Фінансовий план & $\begin{array}{l}\text { Основні фінансові розрахунки, калькуляція собівартості і кошторис витрат на проект, опис джерел } \\
\text { фінансових коштів, таблиця витрат і доходів, рух коштів. Розділ повинна включати: витрати } \\
\text { підготовчого періоду, витрати основного періоду, розрахунок надходжень, витрати, пов'язані } 3 \\
\text { обслуговуванням кредитів, податкові платежі, інші надходження та виплати, звіт про прибутки і } \\
\text { збитки, грошові потоки, прогнозний баланс. }\end{array}$ \\
\hline 8) Ризики і гарантії & $\begin{array}{l}\text { Аналіз чутливості підприємства до зовнішніх чинників. Опис можливих ризиків та гарантії } \\
\text { окупності проекту. }\end{array}$ \\
\hline Додатки & $\begin{array}{l}\text { Всі подробиці, які не ввійшли в основні розділи, можна описати в додатках. Це розвантажить } \\
\text { основну частину від зайвих таблиць, графіків та іншого. }\end{array}$ \\
\hline
\end{tabular}


Важливо звернути увагу на унікальність продукції або послуг: нова технологія, якість товару, низька собівартість чи якесь особливе гідність, яке задовольняє запитам покупців. Також необхідно підкреслити можливість вдосконалення даної продукції (послуги). Описуються наявні патенти або авторські права на винаходи або наводяться інші причини, які могли б перешкодити вторгненню конкурентів на ринок. Такими причинами можуть бути ексклюзивні права на розповсюдження i торгові марки [8].

Маркетинг і збут продукції (послуг). План маркетингу необхідний, щоб потенційні клієнти перетворилися на реальних. Цей план повинен показати, чому клієнти будуть купувати саме цю продукцію або користуватися саме цими послугами. Необхідно продумати і пояснити потенційним партнерам або інвесторам основні елементи свого плану маркетингу: ціноутворення, схему поширення товарів, рекламу, методи стимулювання продажу, організацію післяпродажного супроводу, формування іміджу. До основних аспектів даного розділу слід віднести:

- опис вимог споживачів до продукції (послузі) i можливості задовольнити їх;

- опис конкуренції. Визначити конкурентів і проаналізуйте їх сильні і слабкі сторони, а також свої можливості;

- опис ринку збуту продукції (послуги);

- опис поставки товару від місця виробництва до місця продажу або споживання;

- стратегія залучення споживачів, виходячи 3 визначених можливостей. Ціна і обсяг збуту продукціï. Саме ціна продажу продукту (послуги) визначає, в кінцевому рахунку, величину прибутку, прибутковість проекту. Необхідно забезпечити ув'язку параметрів «ціна - якість - рентабельність».

Виробничий план. У цьому розділі повинні бути описані всі виробничі або інші робочі процеси, що мають місце на підприємстві. Тут ви повинні розглянути всі питання, пов'язані з приміщеннями, їх розташуванням, обладнанням, персоналом. Так само має бути приділено увагу планованому залучення субпідрядників, необхідно пояснити, як організована система випуску продукції (послуг) та як здійснюється контроль над виробничими процесами [9].

Необхідно приділити увагу питанням розташування виробничих площ і розміщення обладнання. Нарешті, в цьому розділі повинні знайти відображення питання, пов'язані $з$ термінами поставок, числом основних постачальників і наскільки швидко може бути збільшений чи скорочений випуск продукції.

Організаційний план. У даному розділі пояснюється, яким чином організована керівна група i описується основна роль кожного ii члена. Показується команда управління проектом та провідні фахівці, правове забезпечення, наявні або можливі підтримка та пільги, організаційна структура і графік реалізації проекту. У цьому розділі повинні бути представлені дані про партнерів, їх можливості та досвід. Потрібно висвітлити механізм підтримки і мотивації провідних керівників, показати яким чином можна зацікавити їх у досягненні поставлених в бізнес-плані цілей. Слід вказати, як буде оплачуватися їх праця (оклад, премії, пайова участь у прибутку тощо).

Фінансовий план. Мета розділу - показати основні пункти з маси фінансових даних. Тут даються норма- тиви для фінансово-економічних розрахунків, наводяться прямі (змінні) і постійні витрати на виробництво продукції, калькуляція собівартості продукції, кошторис витрат на реалізацію проекту, потреба та джерела фінансування, розраховується таблиця витрат і доходів, потік реальних грошей (потік готівки), прогнозний баланс.

Ризики i гарантії. Показуються підприємницькі ризики та можливі форс-мажорні обставини, наводяться гарантії повернення коштів партнерам та інвесторам.

Ефективність проекту. У розділі зазначаються показники ефективності реалізації проекту, проводиться аналіз чутливості проекту, розраховується життєвий цикл проекту, беззбитковий обсяг продажів.

Додатки. Додаток $є$ важливою частиною бізнес-плану, сприяє розвантаженню основного тексту від подробиць і дає можливість надати потенційним партнерам та інвесторам різні додаткові матеріали, а саме, що [10]:

- підтверджують і розкривають відомості про підприємство (копії реєстраційного свідоцтва, статуту та установчого договору підприємства, наявні ліцензії та сертифікати, почесні дипломи та свідоцтва, копії матеріалів преси про діяльність підприємства, відгуки замовників і партнерів по спільній діяльності тощо);

- характеризують продукцію (фото, рисунки, креслення, патент, відгуки, результати випробувань і сертифікації продукції, інші відомості);

- переконують в затребуваності продукції (матеріали маркетингового дослідження, порівняльні дані про конкурентів, договору, протоколи про наміри та заявки на поставку продукції);

- показують можливості виробництва (фотографію підприємства, його провідних ділянок, устаткування, копії документів по сертифікації виробництва тощо);

- розкривають організаційно-правову готовність проекту (схеми організаційної структури, механізму реалізації проекту, виписки з нормативних документів);

- обгрунтовують фінансово-економічні розрахунки (калькуляції, таблиці тощо

- підтверджують спрямованість, значимість (масштабність) і ефективність проекту (рішення, програми, плани, акти, листи, відгуки);

- підтверджують реальність заходів попередження ризику, нейтралізації форс-мажорних обставин і реальність гарантій повернення позики (гарантійні листи, договори, склад і вартість застави, виписка з законодавчих і нормативних документів, інші матеріали).

Отже, професійне обгрунтування інвестицій істотно знижують ризики втрати власних коштів та підвищує можливості залучення коштів від інвесторів по бізнес-проекту.

Висновки. Отже, проведене дослідження дає підстави стверджувати, що бізнес-план є основою роботи будь-якого підприємства, поряд з майновим забезпеченням, входить до мінімуму гарантій для залучення інвестицій. Проте, відсутність продуманого бізнес-плану, ретельно відкоригованого відповідно до мінливих умов, що особливо актуально у сучасних умовах фінансової кризи, є істотним недоліком, що відображає слабкість управління підприємством, ускладнює можливості залучення фінансових ресурсів і досягнення довгострокової стабільності в конкурентному середовищі.

Інвестор чітко розуміє, що якщо підприємство не можете зробити якісний, обгрунтований бізнес-план, то і вкладені інвестиції можуть використовуватися непрофесійно. 


\section{Список використаних джерел:}

1. Чичун В.А., Паламарчук В.Д. Бізнес-планування як фактор успішної підприємницької діяльності // Соціум. Наука. Культура. $-2010 .-21(18) .-86$ с. - С. $58-63$.

2. Планування діяльності фірми: навч.-метод. посібник / Алексєєва М. М. - К.: Фінанси і статистика, 2011. - 248 с.

3. Бізнес-план: технологія розробки та обгрунтування : навч. посібник / Покропивний С. Ф., Соболь С. М., Швиденко Г. О., Дерев 'янко О. Г. - [Вид. 2-ге, доп.]. - К.: КНЕУ, 2010. - 379 с.

4. Смаковська Ю. Критерії експертної оцінки бізнес-плану підприємницікого проекту // Формування ринкової економіки в Україні. - 2009. - № 19. - 518 с. - С. 434-438.

5. Скібіцька Л.І. Антикризовий менеджмент [текст]: навч.посіб. / Л.І.Скібіцька, В.В. Матвєєв, В.І. Щелкунов, С.М. Подрєза.К.: «Центр учбової літератури», 2014. -584 с.

6. Арсеенко А. Підприємництво і підприємці / А. Арсеенко // Урядовий кур'єр. - 2004. - 20 січня № 1(24). - С. 6.

7. Джелла А. Н. Стратегічне планування діяльності підприємства / А. Н. Джелла // Актуальні проблеми економіки: науковий економічний журнал. - К.: Національна академія управління, 2010. - С. 23-26.

8. Литвиненко С. Л. Комплекс бізнес-планування вантажних авіакомпаній / С. Л. Литвиненко // Актуальні проблеми економіки: науковий економічний журнал. - К.: Національна академія управління, 2011. - Вип. 2(116). - С. 89-95.

9. Теоретико-методологічні основи бізнес-планування у вітчизняних вантажних авіакомпаніях: Монографія / за заг. ред. О.В. Мартякової. - Донецьк: ДВНЗ «ДонНТУ», 2010. - 118 с.

10. Пугачевська К.Й., Плют Т.С. Значення бізнес-планування як чинника господарської діяльності в ринковій економіці // Науковий вісник НЛТУ України. - 2011. - № 21.1. - 469 с. - С. 256-260.

11. Державна служба статистики України. URL: http://www.ukrstat.gov.ua/

12. Стандарти бізнес-планування UNIDO. URL: https://studopedia.com.ua/

\section{References:}

1. Chychun, V.A., \& Palamarchuk, V.D. (2010). Biznes-planuvanya yak faktor uspishnoi pidpryemnyckoi diyalnosti [Business planning as a factor of successful business activity]. Sotsium. Nauka. Kultura - Social. Science. Culture., 21(18), 86, 58-64 [in Ukrainian].

2. 2. Alekseyeva, M.M. (2011). Planuvanya diyalnosti firmy [Planning of the firm]. Finansy i statystyka [in Ukrainian]. Kyiv, Finansy i statystyka, 248 [in Ukrainian].

3. Pokropyvnyi, S.F., Sobol, S.M., Shvydenko, H.O. (2010). Biznes-plan: tekhnolohgiya rozrobky ta obgruntuvanya [Business plan: development and justification technology]. Kyiv: KNEU [in Ukrainian].

4. Smakovska, Yu. (2009). Kryterii ekspertnoi otsinky biznes-planu pidpryemnytskohgo proektu [Criteria for peer review of the business plan of an entrepreneurial project]. Formuvany rynkovoi ekonomiky Ukrainy - Formation of market economy in Ukraine, 19, 518, 434-438 [in Ukrainian].

5. Skibitska, L.I., Matveyev, V.V., Shchelkunov, V.I. \& Podreza, S.M. (2014). Antykryzovyi menedzhment [Crisis management]. Tsentr uchbovoi literatury, 584 [in Ukrainian].

6. Arseenko, A. (2004). Pidpryyemnytstvo i pidpryyemtsi [Entrepreneurship and entrepreneurs]. Uryadovui kuryer - Government courier, 1(24), 6 [in Ukrainian].

7. Dzhella, A.N. (2010). Stratehichne planuvanya diyalnosti pidpryyemstva [Strategic planning of enterprise activity]. Aktualni problem ekonomiky: naukovyi ekonomichnyi zhurnal - Current problems of economics: scientific economic journal, 23-26 [in Ukrainian].

8. Lytvynenko, S.L. (2011). Kompleks biznes-planuvanya vantazhnykh aviakompanii [Complex business planning of freight airlines]. Aktualni problem ekonomiky: naukovyi ekonomichnyi zhurnal - Current problems of economics: scientific economic journal, 2(116), 89-95 [in Ukrainian].

9. Martyankova, O.V. (2010). Teoretyko-metodologhichni osnovy biznes-planuvanya u vitchyznyanykh vantazhnykh aviakompaniyakh [Theoretical and methodological bases of business planning in domestic freight airlines]. Donetsk, Don NTU, 118 [in Ukrainian].

10. Puhachevska, K.Y., Plyut, T.S. (2011). Znachenya biznes-planuvanya yak chynnyka hospodarskoi diyalnosti v rynkovii ekonomitsi [The importance of business planning as a factor of economic activity in a market economy]. Naukovyi visnyk NLTU Ukrainy - Scientific Bulletin of NLTU of Ukraine, 21.1, 469, 256-260 [in Ukrainian].

11. Sait resursu «Derzhavnoi sluzhby statystyky Ukrainy» [Site of the resorce «State Statistics Service of Ukraine». www.ukrstat.gov.ua Retrieved from http://www.ukrstat.gov.ua/ [in Ukrainian].

12. Sait resursu «Studopedia» [Site of «Studopedia»]. studopedia.com.ua Retrieved from https://studopedia.com.ua/ [in Ukrainian]. 